\title{
WestVirginiaUniversity
}

THE RESEARCH REPOSITORY @ WVU

West Virginia Agricultural and Forestry Experiment

Davis College of Agriculture, Natural Resources

Station Bulletins

And Design

$1-1-1901$

\section{Poultry experiments : loss of weight in eggs during incubation}

\author{
J. H. Stewart \\ Horace Atwood
}

Follow this and additional works at: https://researchrepository.wvu.edu/ wv_agricultural_and_forestry_experiment_station_bulletins

\section{Digital Commons Citation}

Stewart, J. H. and Atwood, Horace, "Poultry experiments : loss of weight in eggs during incubation" (1901). West Virginia Agricultural and Forestry Experiment Station Bulletins. 73.

https://researchrepository.wvu.edu/wv_agricultural_and_forestry_experiment_station_bulletins/73 @ WVU. It has been accepted for inclusion in West Virginia Agricultural and Forestry Experiment Station Bulletins by an authorized administrator of The Research Repository@WVU. For more information, please contact ian.harmon@mail.wvu.edu. 
West Virginia University Libraries

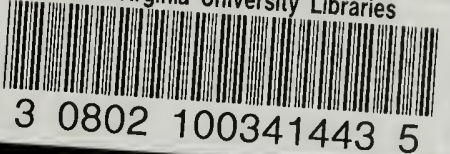

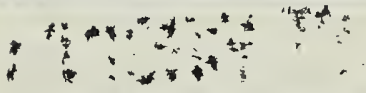

West . Vixginia University Library

This book is due on the date indicated below.

below. ,m

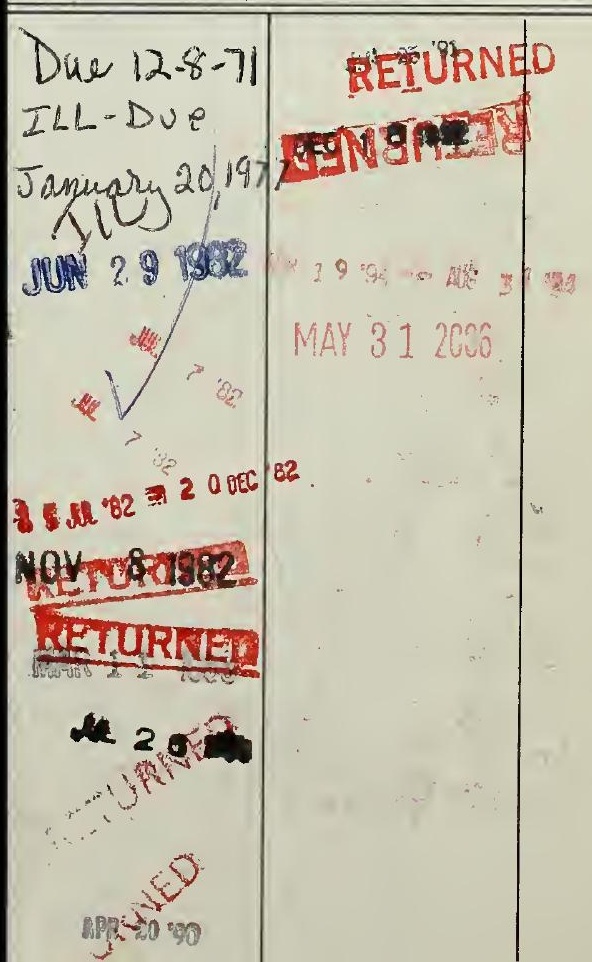



. 



Digitized by the Internet Archive in 2010 with funding from

Lyrasis Members and Sloan Foundation 


\section{WEST VIRGINIA UNIVERSITY \\ AGRICULTURAL EXPERIMENT STATION, \\ MORGANTOWN, W. VA.}

Bulletin 73.

FEBRUARY, 1901.

\section{Poultry Experiments.}

\section{Loss of Weight in Eggs During Incubation.}

By 'J. H. Stewart and Horace Arwood.

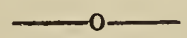

[Thu Bulletins and Reports of this Station will be mailed free to any citizen of West Virginla upon written application. Address Director of Agricultural Experiment Stretion, Morgantown, W. Va.] 


\section{'THE REGENTS OF THE WEST VIRGINIA UNIVERSITY.}

NAME OF REGENT.

Hon George C. Sturgiss

HoN. JAMES F. BRown

Hon. A. H. Kunst

Hon. John J. Davis

HoN. James L. Hamili.

Hon, John A. Campbell

Hon. W. E. Powelt

Hon. P. C. Eastham

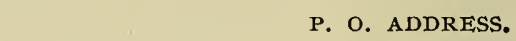

Morgantown

Charleston

Weston

Clarksburg

Welch

New Cumberland

Parkersburg

Pt. Pleasant

\section{STATION COMMITTEE.}

George C. Sturgiss.

JAMES I. Hamill.

JAMES F. BRown.

President of the Board of Regents

Geo. C. Stukigiss

President of the University, Jerome H. Raymond, A. M., Ph. D. Treasurer

Auditor

\section{STATION STAFF.}

James H. Stewart, A. M.

A. D. Hopkins, Ph. D.

Bert H. Hite, M. S.

L. C. Corbett, M. S.

W. E. Roumsey, B.S. Agr.

Horace Atwood, M. S. Agr.

C. D. How a RD, B. S.

E. C. Frame

M. A. Stewart
A. R. Whitehill, Ph. D.

S. G. Chadwick 


\section{CONCERNING LOSS IN WEIGHT OF EGGS DURING INCUBATION.}

Artificial incubation is rapidly assuming immense importance not only on the large poultry farms where all of the hatching is done by incubators, but thousands of people who keep a few hens find that it is easier to hatch by artificial methods. Artificial incubation would be more widely used if poultrymen had some simple and reliable method of determining whether the eggs, while incubating, are receiving the proper amount of ventilation and at the same time are not drying up too rapidly. A proper and uniform temperature can usually be secured in most modern makes of incubators, but at the present time operators rely almost entirely upon experience to determine whether the eggs are kept sufficiently moist, and are receiving enough ventilation for best results. It is true that charts have been constructed showing the proper size of the air cell for each day of the incubating period, but in using a chart considerable experience and good judgment are necessary because the apparent size of the air cells in individual eggs may vary considerably from each other in the same incubator, and the average size of the air cells on any particular day may depart quite widely from the normal without an inexperienced operator realizing that the incubation is not progressing in a satisfactory manner. In addition, the air cells may be of the proper size and yet the embryos may perish either on account of an insufficient amount of oxygen, or because the gases resulting from the growth of the embryos are not carried away with sufficient rapidity.

It is unnecessary to describe in detail the stages in the development of a chick. The chick, however, absorbs oxygen, and moisture and certain gases are thrown off through the shell. 
Under normal conditions the total amount of moisture and gases which have been thrown off at any particular time corresponds to that particular stage in the development of the chick, or in other words, when an egg is incubated under perfectly normal conditions the total loss in the weight of the egg corresponds, within certain limits, to the stage of development of the embryo.

If the operator of an incubator knows how much a certain number of eggs have lost in weight since the beginning of the incubating period and compares this loss with the normal loss of the same number of eggs for the same length of time he will know definitely whether the eggs have decreased properly in weight. If they have lost too much, providing of course that the temperature has been normal, they are drying up too rapidly, and either more moisture should be supplied, or the amount of ventilation should be reduced, but in reducing the circulation of air through the incubating chamber it must be remembured that pure air surrounding the eggs is just as important as a proper temperature; on the other hand, if the eggs are not losing weight as rapidly as they should they are either kept too moist, or they are not receiving the proper amount of ventilation, or perhaps they may be kept too moist and insufficiently ventilated also.

The object of this bulletin is to furnish sufficient data to enable the operators of incubators to exercise a more inte:ligent supervision over the operation of their machines. A number of experiments have been performed to determine the normal loss in the weight of eggs during incubation, and for this purpose the natural method of hatching has been employed. Eggs have been weighed, placed under broody hens in locations suitable for a perfect hatch, re-weighed on a chemical balance at suitable intervals, and the luss determined.

The following tables show the results in detail of three hatches which have been selected from a number of similar tests conducted during the past year.

Test 1. - Eggs placed under a Rhode Island Red hen November 11, 1900. Nest situated in a conol dry cellar: 


\begin{tabular}{|c|c|c|c|c|c|}
\hline Number of Egg. & 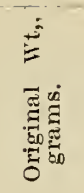 & 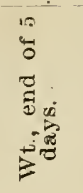 & 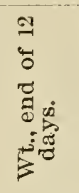 & 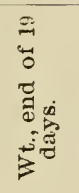 & Result. \\
\hline $1 \ldots \ldots \ldots$ & 58.694 & 56.504 & 52.965 & 49.544 & Hatched. \\
\hline $2 \ldots \quad \ldots \ldots \ldots \ldots \ldots \ldots$ & 63.832 & 61.824 & 58.847 & 56.095 & Unfertile. \\
\hline $3 \ldots \ldots \ldots \ldots \ldots \ldots$ & 60.212 & 58.214 & 54.920 & 51.604 & Dead, $3 / 4$ dereloped. \\
\hline $4 \ldots \ldots \ldots \ldots \ldots \ldots$ & 53.340 & 50.520 & 46.224 & 42. 393 & Hatched. \\
\hline $5 \ldots \ldots \ldots \ldots \ldots \ldots \ldots$ & 52430 & 50.137 & 46.572 & 43.051 & “ \\
\hline $6 \ldots \ldots \ldots \ldots \ldots \ldots \ldots \ldots$ & 50.205 & 47.544 & 43.788 & 40.107 & “ \\
\hline $7 \ldots \ldots \ldots \ldots \ldots \ldots \ldots$ & 49.197 & 47.224 & 44.431 & 41.739 & “ \\
\hline $8 \ldots \ldots \ldots \ldots \ldots \ldots$ & 50.805 & 48.752 & 45.800 & 43.064 & Unfertile. \\
\hline $9 \ldots \ldots \ldots \ldots \ldots \ldots \ldots$ & 55.484 & 53.339 & 50.294 & 47.212 & Hatched. \\
\hline $10 \ldots \ldots \ldots \ldots \ldots \ldots \ldots \ldots$ & 52.585 & 50.435 & 47.184 & 43.970 & Dead, fu,ly developed. \\
\hline
\end{tabular}

Table showing the loss in weight of the eggs which hatched:

\begin{tabular}{|c|c|c|c|c|}
\hline Number of Egg. & $\begin{array}{l}\text { Loss } \\
\text { first } 5 \\
\text { days, }\end{array}$ & $\begin{array}{c}\text { Loss } \\
\text { next } 7 \\
\text { days. }\end{array}$ & $\begin{array}{l}\text { Loss } \\
\text { next } 7 \\
\text { days. }\end{array}$ & $\begin{array}{l}\text { Total } \\
\text { loss for } \\
19 \text { days. }\end{array}$ \\
\hline $1 \ldots \ldots \ldots \ldots \ldots \ldots \ldots \ldots \ldots \ldots \ldots \ldots \ldots$ & 2.190 & 3.539 & 3.421 & 9.150 \\
\hline $4 . \ldots \ldots \ldots \ldots \ldots \ldots \ldots \ldots \ldots \ldots \ldots \ldots \ldots \ldots \ldots \ldots \ldots$ & 2.820 & 4. 296 & 3.831 & 10.947 \\
\hline 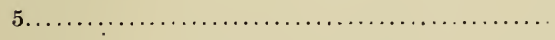 & 2.293 & 3.565 & 3.521 & 9.379 \\
\hline 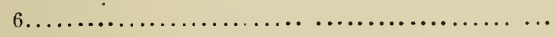 & 2.661 & 3.756 & 3.681 & 10.098 \\
\hline 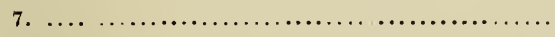 & 1.973 & 2.793 & 2.692 & .7 .458 \\
\hline $9 \ldots \ldots \ldots \ldots \ldots \ldots \ldots \ldots \ldots \ldots \ldots \ldots \ldots \ldots \ldots$ & 2.145 & 3.045 & 3.082 & 8.272 \\
\hline Average loss per egg. $\ldots \ldots \ldots \ldots \ldots \ldots \ldots$ & 2.347 & 3.499 & 3.371 & 9.217 \\
\hline Average loss per day....... & .469 & .499 & .481 & .484 \\
\hline Percentage loss........... & $\underset{4.41}{\text { Per }}$ & $\begin{array}{l}\text { Per ct. } \\
6.87\end{array}$ & $\begin{array}{l}\text { Per ct. } \\
7.11\end{array}$ & $\begin{array}{c}\text { Per ct. } \\
17.31\end{array}$ \\
\hline
\end{tabular}

Table showing the loss in weight of the fertile eggs which did not hateh.

\begin{tabular}{|c|c|c|c|c|}
\hline Number of Egg. & $\begin{array}{l}\text { Loss } \\
\text { first } 5 \\
\text { days. }\end{array}$ & $\begin{array}{l}\text { Loss } \\
\text { next } 7 \\
\text { days. }\end{array}$ & $\begin{array}{l}\text { Loss } \\
\text { next } 7 \\
\text { days. }\end{array}$ & $\begin{array}{c}\text { Total } \\
\text { loss for } \\
19 \text { days. }\end{array}$ \\
\hline $3 \ldots, \ldots \ldots \ldots \ldots \ldots \ldots \ldots \ldots \ldots \ldots \ldots \ldots \ldots \ldots \ldots \ldots \ldots \ldots \ldots$ & 1.968 & 3.324 & 3.316 & 8.608 \\
\hline $10 \ldots \ldots \ldots \ldots \ldots \ldots \ldots \ldots \ldots \ldots \ldots \ldots \ldots \ldots \ldots \ldots \ldots \ldots \ldots \ldots \ldots$ & 2.150 & 2.251 & 3.214 & 8.615 \\
\hline A verage loss per egg...................... & 2.059 & 3.287 & 3.285 & 8.611 \\
\hline Average loss per day & .411 & .469 & .466 & .453 \\
\hline F ercentage loss.... & $\begin{array}{c}\text { Per ct. } \\
3.65\end{array}$ & $\begin{array}{l}\text { Per ct. } \\
6.04\end{array}$ & $\begin{array}{c}\text { Per ct. } \\
6.39\end{array}$ & $\begin{array}{c}\text { Per ct. } \\
15.26\end{array}$ \\
\hline
\end{tabular}


Table showing the loss in weight of the unfertile eggs:

\begin{tabular}{|c|c|c|c|c|}
\hline Number of Egg. & $\begin{array}{l}\text { Loss } \\
\text { first } 5 \\
\text { days. }\end{array}$ & $\begin{array}{c}\text { Loss } \\
\text { next } 7 \\
\text { days. }\end{array}$ & $\begin{array}{c}\text { Loss } \\
\text { next } 7 \\
\text { days, }\end{array}$ & $\begin{array}{c}\text { Total } \\
\text { loss for } \\
19 \text { days. }\end{array}$ \\
\hline $2 \ldots \ldots \ldots \ldots \ldots \ldots \ldots \ldots \ldots$ & 2.008 & 2.977 & 2.752 & 7. 737 \\
\hline 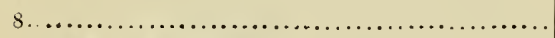 & 2.053 & 2.952 & 2,736 & 7.741 \\
\hline Average loss per egg.................... & 2.030 & 2.964 & 2. 744 & 7.738 \\
\hline Average loss per day. $\ldots \ldots \ldots \ldots \ldots \ldots \ldots \ldots \ldots$ & .406 & .423 & .392 & .407 \\
\hline Percentage loss & $\begin{array}{l}\text { Per ct. } \\
3.54\end{array}$ & $\begin{array}{c}\text { Per ct. } \\
5.36\end{array}$ & $\begin{array}{c}\text { Per ct. } \\
5.24\end{array}$ & $\begin{array}{c}\text { Per ct. } \\
13.50\end{array}$ \\
\hline
\end{tabular}

The preceding tables show that all of the eggs decreased more rapidly in weight during the latter part than during the first part of the incubating period. Also that the unfertile eggs decreased considerably less than the ones which hatched, the eggs in which the germs were weak standing midway between the two extremes.

It is a matter of importance to know whether a heavy egg will decrease more in weight than a lighter one. In order to consider this point we may divide the eggs which hatched in the above test according to their weight. Numbers 1, 4, and 9 had an average weight of 55.839 grams and lost during the nineteen days of the test 9.456 grams, or at the rate of 16.9 per cent. On the other hand the lighter eggs, 5, 6 , and 7 , with an average weight of 50.610 grams, gave an average decrease in weight of 8.978 grams, which is at the rate of 17.7 per cent., it is thus seen that although the larger eggs lost more in weight than the smaller ones, yet they suffered a slightly smaller percentage loss.

TEsT 2.-Esgs placed under a Rhode Island Red hen January 28, 1901. Nest situated in a dry room kept moderately warm: 


\begin{tabular}{|c|c|c|c|c|c|}
\hline Number of Egg. & $\begin{array}{l}\text { Original } \\
\text { weight, } \\
\text { grams. }\end{array}$ & $\begin{array}{l}\text { Weight } \\
\text { at end of } \\
5 \text { days, }\end{array}$ & $\begin{array}{l}\text { Weight } \\
\text { at end of } \\
12 \text { days, }\end{array}$ & $\begin{array}{l}\text { Weight } \\
\text { at eud of } \\
19 \text { days. }\end{array}$ & Result. \\
\hline $1, \ldots \ldots \ldots \ldots \ldots \ldots \ldots, \ldots$ & 54.245 & 51.294 & 47. 109 & 42.516 & Hatched. \\
\hline $2 \ldots \ldots \ldots \ldots \ldots \ldots \ldots \ldots$ & 56.391 & 54.244 & 52.135 & 49.545 & " \\
\hline $3 \ldots \ldots \ldots \ldots \ldots \ldots \ldots \ldots$ & 58.136 & 55.215 & 51.026 & 46.445 & “ \\
\hline $4 \ldots \ldots \ldots \ldots, \ldots \ldots \ldots \ldots$ & 67.391 & 65.081 & 62.125 & 58.866 & “ \\
\hline $5 \ldots \ldots \ldots \ldots \ldots \ldots \ldots \ldots$ & 55.451 & 52.685 & 49.379 & 45.439 & “" \\
\hline $6 \ldots \ldots \ldots \ldots \ldots \ldots \ldots \ldots$ & 64.530 & 61.900 & $58.5: 4$ & 54.734 &. \\
\hline $7 \ldots \ldots \ldots \ldots \ldots \ldots \ldots$ & 59.543 & 57.225 & 54.039 & 50.606 & “ \\
\hline $8 \ldots \ldots \ldots \ldots \ldots \ldots \ldots \ldots$ & 64.481 & 61.882 & 58.419 & 54.590 & . \\
\hline $9 \ldots \ldots \ldots \ldots \ldots \ldots \ldots$ & 62.529 & 60.095 & 56.791 & 53.099 & $\because$ \\
\hline $10 \ldots \ldots \ldots \ldots \ldots \ldots \ldots$ & 56.394 & 53.772 & 50.431 & 46.625 & “ \\
\hline $11, \ldots \ldots \ldots \ldots \ldots \ldots \ldots \ldots$ & 53.991 & 51.799 & Broken. & & \\
\hline $12 . . \ldots \ldots \ldots \ldots \ldots \ldots \ldots$ & 55.201 & 52.980 & 50.062 & 46.785 & Hatched. \\
\hline
\end{tabular}

The above table shows a remarkably good hatch. Twelve eggs were placed under a hen, and with the exception of the one broken after the second weighing, all hatched and the chicks were strong and vigorous.

Table showing the loss in weight of the eggs.

\begin{tabular}{|c|c|c|c|c|}
\hline Number of Egg. & $\begin{array}{l}\text { Loss } \\
\text { first } 5 \\
\text { days. }\end{array}$ & $\begin{array}{c}\text { Loss } \\
\text { next } \\
\text { days. }\end{array}$ & $\begin{array}{c}\text { Loss } \\
\text { next } 7 \\
\text { days. }\end{array}$ & $\begin{array}{c}\text { Total } \\
\text { loss for } \\
19 \text { days. }\end{array}$ \\
\hline $1 \ldots \ldots \ldots \ldots \ldots$ & 2.951 & 4.185 & 4.593 & 11. 729 \\
\hline $2 \ldots \ldots \ldots \ldots \ldots \ldots \ldots \ldots \ldots$ & 2.147 & $2.109^{*}$ & $2.590 *$ & 6.846 \\
\hline $3 \ldots \ldots \ldots \ldots \ldots \ldots \ldots \ldots \ldots \ldots \ldots \ldots \ldots \ldots \ldots \ldots$ & 2.921 & 4.189 & 4.581 & 11.691 \\
\hline 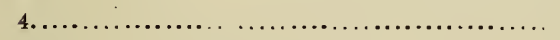 & 2.310 & $2.956 *$ & $3.259^{\%}$ & 8.525 \\
\hline 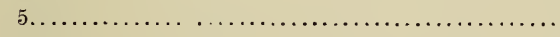 & 2.766 & 3.306 & 3.940 & 10.012 \\
\hline $6 \ldots \ldots \ldots \ldots \ldots \ldots \ldots \ldots \ldots \ldots \ldots \ldots \ldots \ldots \ldots \ldots \ldots$ & 2.630 & 3.366 & 3.800 & 9.796 \\
\hline 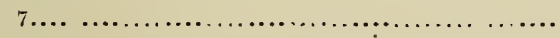 & 2.318 & 3.186 & 3.433 & 8.937 \\
\hline 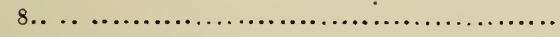 & 2.599 & 3.463 & 3.829 & 9.891 \\
\hline 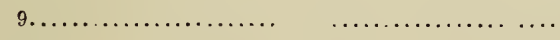 & 2.434 & 3. 304 & 3.692 & 9.430 \\
\hline 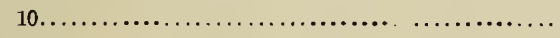 & 2. 622 & 2. 341 & 3.806 & 9.769 \\
\hline 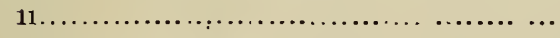 & 2. 192 & & & \\
\hline 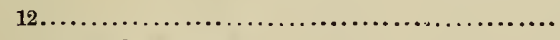 & 2.221 & 2.918 & 3.277 & 8.416 \\
\hline Average loss per egg...................... & 2.538 & 3. 302 & 3. 709 & 9.549 \\
\hline Average loss per day $\ldots \ldots \ldots \ldots \ldots \ldots \ldots \ldots \ldots$ & .507 & .471 & .529 & .502 \\
\hline Percentage loss, $\ldots \ldots \ldots \ldots \ldots \ldots \ldots \ldots \ldots \ldots \ldots$ & $\begin{array}{l}\text { Per ct. } \\
4.26\end{array}$ & $\begin{array}{l}\text { Perct. } \\
5.79\end{array}$ & $\begin{array}{l}\text { Per ct. } \\
6.91\end{array}$ & $\begin{array}{l}\text { Perct. } \\
16.05\end{array}$ \\
\hline
\end{tabular}

* Covered with broken egg.

In this test it is seen that the greatest percentage loss was during the third period, or from the tweifth to the nineteenth day, 
the eggis losing during that time slightly less than 1 per cent. daily, the percentase loss being calculated from the weight of the eggs at the Beginning of the third period.

During the second period, or from the fifth to the twelfth day, the dailv percentage loss is slightly less than during the first five days and also considerably less than during the same period in test 1 . This small loss was undoubtedly due to the breakage of egg No. 11, which would reduce somewhat the temperature of the remaining egge during this period, and by partially covering numbers 2 and 4 prevent them from decreasing as much as they otherwise would.

Large Versus Shall Eggs.-Dividing the eggs into two groups according to their weight we have numwers $4,6,7,8$, and 9 with sn average weight of 63.695 grams and with an average loss of 9.315 grams. The remaining eggs whose average is 55.969 grams lost an average weight of 9.744 grams. Consequently in this test the lighter eggs lost more weight than the others.

Test 3.-Eggs placed under a Rhode Island Red hen February 1, 1901. Nest situated in a room kept moderately warm except during the last five days of the hatch, when the temperature unavoidably fell nearly to the freezing point.

\begin{tabular}{|c|c|c|c|c|c|}
\hline umber of Egg. & $\begin{array}{l}\text { Original } \\
\text { weight, } \\
\text { grams. }\end{array}$ & $\begin{array}{l}\text { Weight } \\
\text { at end of } \\
5 \text { days. }\end{array}$ & $\begin{array}{l}\text { Weight } \\
\text { at end of } \\
12 \text { days. }\end{array}$ & $\begin{array}{l}\text { Weight } \\
\text { at end of } \\
19 \text { days. }\end{array}$ & Result. \\
\hline 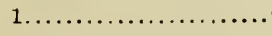 & 64.294 & 62.257 & 59.204 & 56.088 & Unfertile. \\
\hline $2 \ldots \ldots \ldots \ldots \ldots \ldots \ldots$ & 66.885 & 64.410 & 60.631 & 56.820 & Hatched. \\
\hline $8 \ldots \ldots \ldots \ldots \ldots \ldots \ldots \ldots$ & 67.994 & 65.340 & 61.026 & 56.665 & Dead in shell. \\
\hline 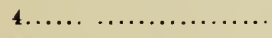 & 56.868 & 55.026 & 52.056 & 49.000 & Hatched. \\
\hline$s \ldots \ldots \ldots \ldots \ldots \ldots$ & 66.790 & 64. 159 & 60.016 & 56.001 & Dead in shell. \\
\hline $6 \ldots \ldots \ldots \ldots \ldots \ldots \ldots$ & 60.080 & 57.487 & 53.536 & 49.864 & Unfertile. \\
\hline $7 \ldots \ldots \ldots \ldots$ & 55.915 & 53.768 & 50.305 & 46.819 & Hatched. \\
\hline $8 \ldots \ldots \ldots \ldots \ldots$ & 57.160 & 55.012 & 51.776 & 48.191 & “" \\
\hline & 59.189 & 56.916 & 53.134 & 49.229 & “" \\
\hline $10 \ldots \ldots \ldots \ldots \ldots \ldots$ & 54.324 & 52.204 & 48.707 & 45.274 & “" \\
\hline $11 \ldots \ldots \ldots \ldots \ldots \ldots \ldots$ & 52.793 & 50.351 & 46.501 & 42.845 & “. \\
\hline $12 \ldots \ldots \ldots \ldots \ldots \ldots$ & 48.880 & 46.821 & 43.505 & 40.107 & “" \\
\hline $13 \ldots \ldots \ldots \ldots \ldots \ldots$ & 53.121 & 51.114 & 47.947 & 44. 721 & "، \\
\hline
\end{tabular}

Of the thirteen eggs all hatched but four, two of the eggs being unfertile and two with weak germs. 
The foilowing table shows the Ioss in weight of each egg which hatched for each of the three periods, and the total loss for the nineteen days of the test:

\begin{tabular}{|c|c|c|c|c|}
\hline Number of Egg & $\begin{array}{l}\text { Loss } \\
\text { first } 5 \\
\text { days. }\end{array}$ & $\begin{array}{l}\text { Loss } \\
\text { next } 7 \\
\text { days. }\end{array}$ & $\begin{array}{l}\text { Loss } \\
\text { next } 7 \\
\text { days. }\end{array}$ & $\begin{array}{l}\text { Total } \\
\text { loss for } \\
19 \text { days. }\end{array}$ \\
\hline $2 \ldots \ldots \ldots \ldots \ldots \ldots \ldots \ldots \ldots \ldots \ldots$ & 2.475 & 3.779 & 3.811 & 10.065 \\
\hline 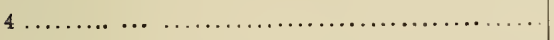 & 1.842 & 2.970 & 3.0 .56 & $7.86 \mathrm{~s}$ \\
\hline $7 \ldots \ldots \ldots \ldots \ldots \ldots \ldots \ldots \ldots \ldots \ldots \ldots \ldots \ldots \ldots \ldots \ldots \ldots \ldots$, & 2.147 & 3.463 & 3.486 & 9.096 \\
\hline 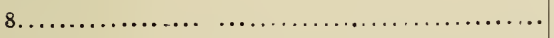 & 2.148 & 3.236 & $\therefore .585$ & 8.9199 \\
\hline 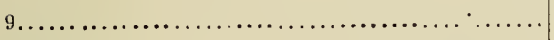 & 2. 243 & 3.812 & $3 .: 05$ & 9.960 \\
\hline 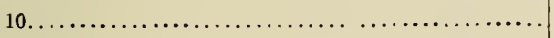 & 2.120 & 3.497 & 3.433 & 9.0 .50 \\
\hline $11 \ldots \ldots \ldots \ldots \ldots \ldots \ldots \ldots \ldots \ldots \ldots \ldots \ldots \ldots \ldots \ldots \ldots \ldots \ldots \ldots$, & 2.442 & 3.850 & 3.656 & 9.948 \\
\hline 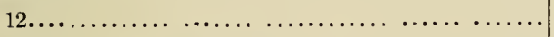 & 2.059 & 3.316 & 3.89 & 9.773 \\
\hline 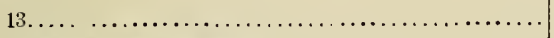 & 2.007 & 3.167 & $3.2: 6$ & 3. 400 \\
\hline Average loss per egg $\ldots \ldots \ldots \ldots \ldots \ldots \ldots \ldots \ldots$ & 2. 164 & 3.454 & 3.506 & 9.125 \\
\hline Average loss per day. $\ldots \ldots \ldots \ldots \ldots \ldots \ldots \ldots$ & .433 & .493 & .501 & $.4 \times 0$ \\
\hline Percentage loss. $\ldots \ldots \ldots \ldots \ldots \ldots \ldots \ldots, \ldots \ldots \ldots$ & $\begin{array}{l}\text { Per ct. } \\
\text { 3.85 }\end{array}$ & $\begin{array}{l}\text { Per ct } \\
6.40\end{array}$ & $\begin{array}{l}\text { Per ct. } \\
6.94\end{array}$ & $\begin{array}{l}\text { Per ct. } \\
16.2 \%\end{array}$ \\
\hline
\end{tabular}

Table showing the loss in weight of the fertile eggs which did not hatch:

\begin{tabular}{|c|c|c|c|c|}
\hline Number of Egg. & $\begin{array}{l}\text { Loss } \\
\text { first } 5 \\
\text { days. }\end{array}$ & $\begin{array}{l}\text { Loss } \\
\text { next } 7 \\
\text { days. }\end{array}$ & $\begin{array}{c}\text { Loss } \\
\text { ext } 7 \\
\text { days. }\end{array}$ & $\begin{array}{l}\text { Total } \\
\text { loss for } \\
19 \text { days. }\end{array}$ \\
\hline ................ & 2. 654 & 4. 314 & 4.361 & 11.329 \\
\hline 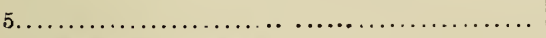 & 2.631 & $4.11: 3$ & 4.045 & 10. 789 \\
\hline Average loss per egg. $\ldots \ldots \ldots \ldots \ldots \ldots \ldots \ldots$ & 2.642 & 4.213 & 4.203 & 11.058 \\
\hline Average loss per day................... & .528 & .602 & .600 & .582 \\
\hline Percentage loss ........ & $\begin{array}{l}\text { Per ct. } \\
3.92\end{array}$ & $\begin{array}{l}\text { Per ct. } \\
6.5\end{array}$ & $\begin{array}{l}\text { Per ct. } \\
6.94\end{array}$ & $\begin{array}{l}\text { Per ct. } \\
16.41\end{array}$ \\
\hline
\end{tabular}

Table showing the loss in weight of the unfertile eggs:

\begin{tabular}{|c|c|c|c|c|c|}
\hline Number of Egg. & - & $\begin{array}{l}\text { Loss } \\
\text { first } 5 \\
\text { days. }\end{array}$ & $\begin{array}{c}\text { Loss } \\
\text { Next } 7 \\
\text { days. }\end{array}$ & $\begin{array}{c}\text { Loss } \\
\text { next } 7 \\
\text { days. }\end{array}$ & $\begin{array}{l}\text { Total } \\
\text { loss for } \\
19 \text { days. }\end{array}$ \\
\hline $1 . \ldots \ldots \ldots \ldots \ldots \ldots \ldots \ldots$ & $\therefore \ldots$ & 2.037 & 3.053 & 3.116 & 8.208 \\
\hline $6 \ldots \ldots \ldots \ldots \ldots \ldots \ldots \ldots \ldots \ldots$ & $\ldots \ldots \ldots$ & 2.593 & 3.951 & 3.672 & 10.216 \\
\hline Average loss per egg...$\ldots \ldots$. & & 2.315 & 3.502 & 3.394 & 9.211 \\
\hline Average loss per day ......... & $\ldots \ldots \ldots$ & .463 & $.50 u$ & .485 & .484 \\
\hline Percentage loss. & & $\underset{3.72}{\text { Per ct. }}$ & $\begin{array}{l}\text { Per ct. } \\
5.84\end{array}$ & $\begin{array}{l}\text { Per cl. } \\
6.02\end{array}$ & $\begin{array}{l}\text { Per ct. } \\
14.81\end{array}$ \\
\hline
\end{tabular}


An inspection of the above tables shows that the eggs w?ich hatched decreased more rapidly in weight during the latter part than during the first part of the period of incubation. The two fertile eggs which did not hatch lost almost the same amount of weight as the eggs which hatched; the dead chicks were perfectly fcrmed, but for some unknown reason were not batched. The unfertile eggs, as in test no 1 , did not lose so much weight as the fertile ones.

The Loss in Weight of Large Versus Small Eggs. - We may divide the eggs which hatched in the above test according to their original weight. Eggs 2, 4, 8, and 9 having an average weight of 60.025 grams, suffered an average loss of 9.215 grams, or at the rate of 15.35 per cent. Eggs 7, 10, 11, 12, and 13, with an average weight of 53.006 grams, gave an average decrease of 9.053 grams, or at the rate of 17.07 per cent. It is thus seen that although the larger eggs lost more weight than the smaller, yet they lost a smaller per cent. of their original weight.

The following table shows the loss in weight of the egg which hatched in the three different tests:

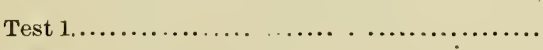

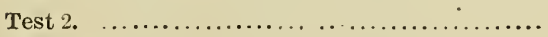

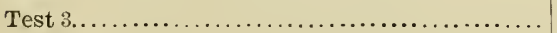

Average.

Total loss per Egg During-

\begin{tabular}{|c|c|c|c}
\hline $\begin{array}{c}\text { First 5 } \\
\text { days. }\end{array}$ & $\begin{array}{c}\text { Next 7 } \\
\text { days. }\end{array}$ & $\begin{array}{c}\text { Next 7 } \\
\text { days. }\end{array}$ & 19 days. \\
\hline 2.317 & 3.499 & 3.371 & 9.217 \\
2.538 & 3.302 & 3.709 & 9.549 \\
2.164 & 3.454 & 3.506 & 9.124 \\
2.349 & 3.418 & 3.528 & 9.297 \\
\hline
\end{tabular}

The following table shows the percentage loss in weight of the eggs which hatched: 
P. reentage Loss of Weight for-

Test 1

Test 2

Test 3.

Average

Average daily loss

\begin{tabular}{|r|r|r|r}
\hline $\begin{array}{c}\text { First 5 } \\
\text { days. }\end{array}$ & $\begin{array}{c}\text { Next 7 } \\
\text { days. }\end{array}$ & $\begin{array}{c}\text { Next 7 } \\
\text { days. }\end{array}$ & 19 days: \\
\hline 4.41 & 6.87 & 7.11 & 17.31 \\
4.26 & 5.79 & 6.91 & 16.05 \\
3.85 & 6.40 & 6.94 & 1.6 .25 \\
4.17 & 6.35 & 6.95 & 16.55 \\
.83 & .90 & 1.00 & .87
\end{tabular}

The above tables show that in the case of the eggs which hatched the daily as well as the percentage loss increased as the period of incubation advanced.

The following table shows the average loss in weight of the fertile eggs which did not hatch:

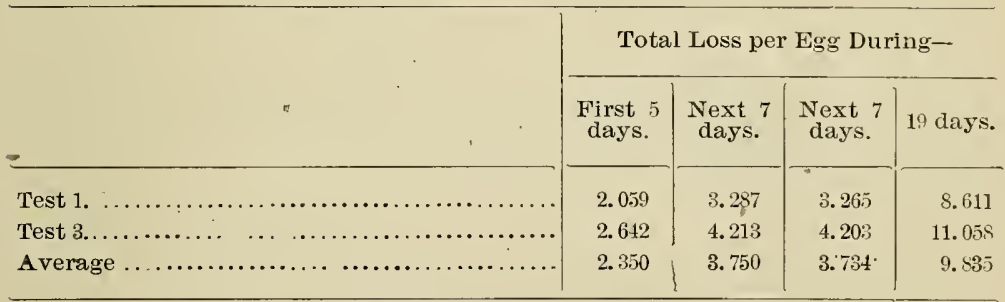

The following table shows the percentage loss of the same eggs:

\begin{tabular}{|c|c|c|c|c|}
\hline & \multicolumn{4}{|c|}{ Average percentage loss during- } \\
\hline . & $\begin{array}{c}\text { First } 5 \\
\text { days. }\end{array}$ & $\begin{array}{c}\text { Next } 7 \\
\text { days. }\end{array}$ & $\begin{array}{c}\text { Next } 7 \\
\text { days. }\end{array}$ & 19 days. \\
\hline Test $1 \ldots \ldots \ldots \ldots$ & 3,65 & 6.04 & 6,39 & 15.26 \\
\hline Test $3 . \ldots \ldots \ldots \ldots \ldots \ldots \ldots \ldots \ldots \ldots \ldots \ldots \ldots \ldots \ldots \ldots \ldots \ldots \ldots \ldots \ldots$ & 3.92 & 6.50 & 6.94 & $16.41^{-3}$ \\
\hline Average..................................... & 3.78 & 6.27 & 6.66 & $15.8 \overline{3}=$ \\
\hline Average daily loss.......................... & .75 & .89 & .95 & $.83^{-2}$ \\
\hline
\end{tabular}

The average loss in weight of the unfertile eggs is shown below: 


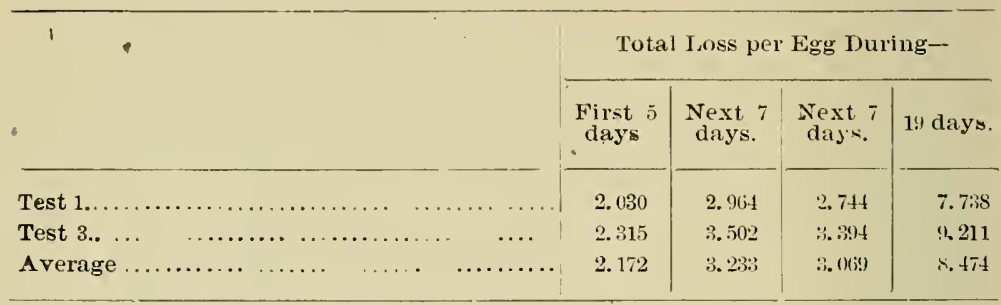

The following table shows the percentage loss of the same eggs:

Test 1

Test

Average.

Average daily loss

Average Percentage Loss During-

\begin{tabular}{|c|c|c|c|}
\hline $\begin{array}{c}\text { First } 5 \\
\text { days. }\end{array}$ & $\begin{array}{c}\text { Next } 7 \\
\text { days. }\end{array}$ & $\begin{array}{l}\text { Next } 7 \\
\text { days. }\end{array}$ & 19 Jays. \\
\hline 3.54 & 5. 36 & 5.24 & 13.50 \\
\hline 3. 72 & 5. 84 & 5.12 & 14.81 \\
\hline 3.63 & 5.60 & 5.63 & 14.15 \\
\hline .72 & .80 & .80 & 7.44 \\
\hline
\end{tabular}

In the following table are brought together the results of the preceding averages:

\section{Total Loss per Egg During-}

\begin{tabular}{|c|c|c|c|c|}
\hline & $\begin{array}{c}\text { First } 5 \\
\text { days. }\end{array}$ & $\begin{array}{l}\text { Next } 7 \\
\text { days. }\end{array}$ & $\begin{array}{c}\text { Next } 7 \\
\text { days. }\end{array}$ & 19 days. \\
\hline \multirow[b]{2}{*}{ Eggs which hatched........ } & 2.349 & 3.418 & 3.528 & 9.297 \\
\hline & $\begin{array}{c}\text { Per ct. } \\
4.17\end{array}$ & $\begin{array}{l}\text { Per ct. } \\
6,3 \%\end{array}$ & $\begin{array}{l}\text { Perct. } \\
6.18\end{array}$ & $\begin{array}{l}\text { Perct. } \\
16.54\end{array}$ \\
\hline \multirow{2}{*}{ Fertile eggs which did not hatch.. ...... } & 2.370 & 3750 & 3.734 & (4. 835 \\
\hline & $\begin{array}{l}\text { Perct. } \\
3.78\end{array}$ & $\begin{array}{c}\text { Per ct. } \\
6.27\end{array}$ & $\begin{array}{c}\text { Per ct. } \\
\text { ti. iti }\end{array}$ & $\begin{array}{c}\text { Per ct. } \\
15.83\end{array}$ \\
\hline \multirow[b]{2}{*}{ Unfertile pggs............................. } & 2.172 & 3. 273 & 3.069 & $8 .+74$ \\
\hline & $\begin{array}{l}\text { Per ct. } \\
3.60\end{array}$ & $\begin{array}{l}\text { Per cl. } \\
\text { 5. to } 0\end{array}$ & $\begin{array}{l}\text { Per ct. } \\
5.633\end{array}$ & $\begin{array}{c}\text { Per ct. } \\
14.15\end{array}$ \\
\hline
\end{tabular}

The table shows that the eggs which hatched lost, luring the 19 day's of the test, a greater persentage of their original weight than either the unfertile eggs or those with weak germs. Also in the case of the fertile eggs the daily loss increased as the incubation proceeded. 


\section{Summary and Conclusion.}

1. Fertile eggs, when incubated in a normal manner, decrease in weight.

2. The eggs which hatched lost 4.17 per cent. of their weight during the first five days of incubation. During the seven succeeding davs they lost 6.35 per cent of the weight of the eggs at the end of the fifth day, and during the next seven days lost 6.98 per cent. of their weight at the end of the twelfth day.

3. One hundred fertile eggs of average size will lose 234.9 grams, or 8.28 ounces. during the first five days of incubation; 341.8 grams, or 12.05 ounces, during the next seven days; and 352.8 grams, or 12.44 ounces, during the next seven days.

4. The unfertile egrgs lost 3.6 per cent. of their original weight during the first five days of incribation. During the seven succeeding days they lost 5.6 per cent. of what they weighed at the end of the fifth day, and during the next seven days lost 5.6 per cent. of their wcight on the twelfth day.

One hundred unfertile eggs will lose 217.2 grams, or 7.66 ounces, during the first five davs ; 323.3 grams, or 11.40 ounces, during the next seven days; 306.9 grams, or 10.82 ounces, during the next seven days.

Suggestions Concerning the Use of These Results.

Before placing eggs in an incubator they should be weighad upon a pair of scales reading to ounces. This may be done very conveniently by first weighing the trays, placing the eggs upon them ready for the incubator, and theli weighing trays and eggs together. The difference will be the weight of the eggs. At the end of the fifth day the eggs and trays should bs re-weighed, the loss in weight determined, and compared with the figures given in the Summary and Conclusion of this bulletin. It is important, however. that the trays be thoroughly dry when first weighed, as wooden trays, especially when recently washed, may appear quite dry and yet contain several ounces of water, which will evaprrate when the trays are placerl in the incubator, and thus make the loss in weight of the eggs during the first five days appear larger than it really is.

Horace ATwood. 


\section{NOTICE.}

Application for bulletins of this Station should be addressed to the Director of the West Virginia Agricultural Experiment Station, Morgantown, W. Va.

(The bulletins named below are available for distribution.)

No. 4. The Creamery Industry; Its Adaptability to West Virginia

No. 5. The Selection of Milch Cows.

No. 14. Farm and Garden Insects and Experiments with Remelies; Notes of the Season.

No. 15. Raspberry Gouty-Gall Beetle.

No. 16. Yellow Locust, Insect Ravages upon.

No. 17. Black Spruce, Insect Ravages.

No. 19. Your Weeds and Your Neighbor's, Part 1. Weeds as Fertilizers.

No. 25. Plat Experiments with Coi..mercial Fertilizers on Wheat.

No. 27. Notes on Pruning.

No. 28. Plat Experiments with Commercial Fertilizers on Corn.

No. 29. Experimentis with Potatoes at the Station. Experiments on Corn at the Out Stations.

No. 30 Address and Notes on Sheep.

No. 33. Sub-Irrigation in thie Green House.

No. 38. Potato Blight, Potato Scab.

No. 42. Vegetables.

No. 43. When, Why, What and How to Spray.

No 44. Practical Entomology.

Special Bulletin No. 2. Proceedings connected with the celebration upon the completion of the Station Building and the organization of the Sheep Breeders and Wool Growers' Association and the State Horticultural Society. 
Third Annual Report, 1896.

No. 54. Nursery Hints.

No. 55. Sugar Beets.

No. 58. The Effect of Fressure in the Preservation of Milk.

No. 59. Whole Corn Compared with Corn Meal for Fattening

No. 60. Poultry Experiments.

No. 61. Sheep Feeding Experiments.

No. 62. A Study of the Effects of Incandescent Gas-light on Plant Growti.

No. 64. Sugar Beet Investigation in 1899 .

No. 66. Fruit Diserses and How to Treat Them.

No. 67. The Hessian Fly in West Virginia.

No. 68. Periodiç, Cicada or Seventeen-year Locust in West Virginia.

No. 69. Report on Examination of Wheat Stubble from Different Sections of the State, and on the Joint Worm in Wheat.

No. 70. Spraying.

No. 71. Poultry Experiments.

No. 72. Commercial Fertilizers 





$\sqrt{3}$ 
